\title{
The Role of Peer to Peer Lending in Increasing Funding for Micro, Small, and Medium Enterprises
}

\author{
Nanik Linawati", Moeljadi Moeljadi, Djumahir Djumahir, and Siti Aisjah \\ Department of Management, Faculty of Economics and Business, Brawijaya University, \\ Jl. MT. Haryono No.165, Malang 65300, East Java, Indonesia
}

\begin{abstract}
This study aims to describe the potential of MSMEs in Indonesia and the role of technology in the industrial era 4.0, especially in alternative funding in the form of Peer to Peer (P2P) Lending in providing funding solutions for MSMEs. This study uses a literature review including academic studies on MSME financing in Indonesia by using the results of previous studies and surveys on Indonesian MSME. The development of P2P Lending is the solution for MSMEs with no access to financial aid from banks.

Keywords: Driving factors for business productivity, fin-tech, increase gross domestic product, strengthen small businesses.
\end{abstract}

\section{Introduction}

Indonesia is a country with enormous natural potential, a large workforce of young workers, and abroad, dynamic market [1]. Another potential possessed by Indonesia is having the fourth largest population in the world [2]. The largest proportion of Indonesia's population is owned by the productive, working-age population (around $60 \%$ ), which has great potential to increase Indonesia's economic growth.

But the total population of Indonesia has not been met with an increase in the welfare of its population. The productivity of the Indonesian population per capita is estimated at $32 \%$ of the productivity per capita of the population of the United States. Therefore, Indonesia needs to find ways to increase Gross Domestic Product (GDP) per capita in order to be able to achieve the welfare achieved by other countries [3].

This projection shows that there are 'missed welfare opportunities' that have not been enjoyed by the working-age population in Indonesia. Some working-age populations do not benefit from higher GDP per capita. Efforts to maximize economic potential and access to funding is a major prerequisite for the population of Indonesia [4], especially for the portion of the population that is doing business at MSMEs. Providing equal access to funding will greatly contribute in creating a multiplier effect on the Indonesian economy. One key element that can drive economic growth effectively is the use of credit to increase production capabilities. Based on the ability to disburse loans per GDP, Indonesia has a very low capability when compared to other countries [3].

\footnotetext{
*Corresponding author: nanikl@petra.ac.id
} 
Since 2004, the Indonesian government has been persistently promoting MSMEs as a driving force for the growth of lower-income communities. As a step towards realizing this objective, the government issued a comprehensive reform economic policy known as the New Economic Policy Package in 2007 and 2008. This package includes policies to improve the investment, financial, and infrastructure sectors. One of the priority objectives of the New Economic Policy is to strengthen small businesses. Moreover, the government also issued UU UKM (UU No.20/2008), aimed at all government authorities and Bank Indonesia, which are expected to have an impact on SMEs that were announced in 2012, concerning the Micro Finance Law contained in UU No.1/2013 [5].

Indonesia's experience in the economic area proves that Micro, Small and Medium Enterprises (MSMEs) plays an important and strategic role in Indonesia's economic growth. MSMEs play a role in contributing to economic growth and employment in Indonesia, as well as in distributing the results of economic growth. MSMEs are also resistant to economic crises. When the economic crisis occurred in the period 1997 to 1998, SMEs were able to stay afloat. After the economic crisis of 1997 to 1998, the number of MSMEs did not decrease. Instead it continued to increase and was even able to absorb $85 \times 10^{6}$ to $107 \times 10^{6}$ workers until 2012. In 2012, the number of employers in Indonesia was 56539 560 units. Of these, the Micro, Small and Medium Enterprises (MSMEs) amounted to 56 534592 units or $99.99 \%$ [6].

Parallel to the development of digital technology in the Industry 4.0 era, Indonesian MSMEs have the opportunity to obtain alternative funding as well as a media to market their products or services online. This means digital technology has played an important role in the development of Indonesia's MSMEs. Technology has become one of the driving factors for business productivity, MSMEs included [7]. The use of e-commerce in the marketing of MSME products has been effective. Thus, MSMEs are continuously encouraged to go digital [8].

If Indonesia focuses on investments in digital technology, particularly in terms of improving digital infrastructure, increasing penetration, and increasing productivity, then the Indonesian economy will reach USD $150 \times 10^{9} \mathrm{yr}^{-1}$ by 2025 . This is a condition that cannot be ignored. If Indonesia adopts a holistic digital strategy, it will empower Indonesian companies to win in the digital era and lift Indonesia's economic growth to the next level. As such, Indonesia must be prepared to benefit greatly from the digital revolution to accelerate economic progress in the public and private sectors [9].

Digital technology helps Indonesian MSMEs grow faster and be internationally competitive. MSMEs that utilize digital technology are able to innovate, make breakthroughs in doing business, and compete in the international market. One form of digital technology in finance that has succeeded in helping the financial difficulties of SMEs, which in the past was a big problem in China for decades, is P2P Lending. In recent years, P2P Lending as a financial industry innovation has been widely accepted by financial markets throughout the world. P2P Lending is proven to be able to connect investors with those who need funding, so it is considered as a solution to solving MSMEs financial problems. A study that examined the use of P2P Lending as an external financial source found that $\mathrm{P} 2 \mathrm{P}$ Lending was a major force to help MSMEs in dealing with financial difficulties. P2P Lending is an internet technology application that has been proven to have a significant ability to connect capital owners with individuals or organizations that need funding, making P2P Lending an effective solution to overcome the difficulties of SME financing [10]. 


\section{Theories}

\subsection{MSMEs characteristic}

Indonesia does not have a homogenous MSMEs group, but rather diverse, separated into subcategories. They can be easily identified from the distinct characteristics in various aspects, such as ways in doing business, market orientation, social-economic profiles of the owners/producers, nature of workers used, adopted organization and management system, level of mechanization (nature of production process), sources of raw materials and capital, location, external relationships, and proportion of women's involvement as entrepreneurs [7].

\subsection{Fin-Tech - peer to peer lending}

Fintech is able to provide services that go beyond conventional banking, in terms of money transfer/remittance, crowdfunding, P2P (Peer-to-Peer)/marketplace loans, and others. One of Fintech's services that provides the highest added value is mobile-payment/e-Wallets. Other services that Fintech provides include financial consulting, data analysis especially big data, the credit assessment, insurance, and others. Fintech services are more than just banks; they can even replace conventional insurance services.

Fintech's excellence is supported by its ability to combine low cost with technology so that it can operate with a lower margin. It is also supported by the use of intense technology, including onboarding, social networking, crowd knowledge, and big data used for market analysis and credit scoring. The use of AI with cybersecurity that is needed in the use of private keys and touch recognition is equally important to ensure customer's trust. There are several companies that are developing Fintech, namely Telecom Fintech (M-PESA), Fintech Social Media (Fidor), and e-commerce Fintech (Alibaba Group).

There are many ways for Bank Fidor to engage customers, such as through social media and the Internet community, making it possible for customers to rate products and assess bank advisers. This method is appreciated by social media users, as evidenced by the large number of "likes" that can be generated, while at the same time requiring only a low fee. P2P Lending SMAVA applies a concept centered on openness. It carries out the development by facilitating communities where members can share advice in forums and collaborate on product development. In addition, the bank provides a platform in the app store to provide independent services to third parties [11]

\section{Methodology}

This study uses a literature review including academic studies on MSME financing in Indonesia by using the results of previous studies and surveys in Indonesian MSMEs from 2011 to 2019, and the development of Peer to Peer Lending in supporting MSMEs' financing in Indonesia.

\section{Analysis}

\subsection{MSMEs in Indonesia}

Based on Indonesian Government Regulation no. 20/2008, the MSMEs are categorized into four groups: 
Table 1. Types of MSMEs in Indonesia

\begin{tabular}{|l|l|l|}
\hline Types of Enterprise & \multicolumn{1}{|c|}{$\begin{array}{c}\text { Asset Value } \\
\text { (Million IDR) }\end{array}$} & \multicolumn{1}{c|}{$\begin{array}{c}\text { Annual Sales } \\
\text { (Million IDR) }\end{array}$} \\
\hline Micro & Less than 50 & Less than 300 \\
\hline Small & 50 up to 500 & 300 up to 2 500 \\
\hline Medium & 500 up to 10 000 & 2500 up to 50 000 \\
\hline Large & More than 10 000 & More than 50 000 \\
\hline
\end{tabular}

Source: ILO, 2019.

As for lending by the various classes of banks to all types of MSMEs in Table 1, at the end of 2017, there was IDR $883 \times 10^{12}$ outstanding in credits to MSMEs. It shows that the state-owned banks dominate the overall category (56\%), with $73 \%$ of the total loans going to MSMEs.

Moreover, in 2017, World Bank reported that bank credit is centered on large corporates and state-owned companies, while MSMEs remain largely underserved. Besides this, the cost of servicing MSMEs loans is higher than the corporate loan. Indonesian MSMEs face significant difficulties in accessing financing, basically due to the stringent operational, reporting and collateral requirements of commercial banks. Despite different government initiatives, the share of MSME loans to total bank credits stands at around $16 \%$ [5]. For so long, MSMEs have been put in a disadvantaged position in terms of funding. They are subject to what we call "Credit Rationing," which makes it very difficult for them to get access to finance. They have a lot of potentials, but access to finance is a critical issue [12].

\subsection{Technology facilitates MSME financing}

Information technology has changed the way to market products and services, so it becomes an interactive process. The company not only provides product catalogs and promotions on its website, but it also uses dialogue, discussion, and consultation with consumers online [13]. Moreover, digital technology helps MSMEs in Indonesia grow faster and become more competitive internationally. A study conducted by Deloitte found a link between the level of use of digital technology and the increase in MSME revenue [14].

Since the presence of Fintech, the bank's brand has declined. The MSMEs state that the bank services have a lack of transparency, a long wait period for the credit decision, difficulties in the application process, unfavorable repayment terms, and a high-interest rate. Meanwhile, based on SWOT analysis, banks have points in Strengths for great customer relationships, deep local knowledge, and a long-term view. But their weaknesses are, they are small scale (budget, technical expertise), lacks digital data, and have a bifurcated customer base. In spite of this, banks have opportunities to build on existing customer relationships, cooperation with the partners to implement digital technologies, emphasize local knowledge, and digital leverage to more fully embrace the ecosystem (e.g., local merchants and charitable causes). Whereas banks have threats in an aging customer base, competitors using technology to offer more compelling products based on digital insights and Fintech competitors.

One of the reasons for the lag in the delivery of digital capabilities on the bank is the comfort of current relationships. While these relationships served the banking industry well in the past, the financial services industry needs to change the underlying processes to accept the new forms of data, especially real-time digital processing.

Omnichannel customer engagement should not be a bolt-on product that can simply be added to existing systems to give a little more functionality. Banks need to take a fresh perspective-wiping the established offline board [15]. 
Development of P2P's digital platform, whose paper-less and presence-less process cuts intermediary cost, may offer faster and cheaper credit. P2P lending is offering a ray of hope to a large chunk of the unbanked, like MSMEs.

\subsection{Characteristic of Indonesia's fintech lending}

Indonesia has a specific feature of the Fintech Lending atmosphere because of the character of its market and regulation. The development of Indonesia's Fintech Lending cannot be easily compared to other countries, as the majority of Indonesian MSMEs have limited physical and data.

Most of Fintech Lending's clients come from the "Credit Invisible"- MSMEs, which previously had no access to credit. There are still huge untapped opportunities, particularly outside Java, because of difficulties in physical outreach and data availability.

There is a tendency of over-leveraged debt behavior, hence requiring an integrated lending database to prevent misconduct. Particularly debt refinancing that gives off an impression of the top three loan purposes, indicating the potential for 'over-leveraged' debt behavior. So, an integrated database covering conventional and online lending may be required.

The development of credit payment is subsequently followed by the development of NPL. OJK is currently implementing TKB90 to guarantee players to unveil their credit execution, which may prevent irresponsible conduct.

As the industry develops, adjusting demand and supply in the platform becomes a critical point. Through cooperation with Financial Institutions and tech companies, players may have a progressively steady source of funds, while likewise expanding the use of their loan portfolio in more instances. The capability to develop cooperation becomes a musthave competitive advantage for players.

Because of supportive regulation and expanding use cases, we predict that Fintech Lending will have the potential to get accumulative loan disbursements of IDR $223 \times 10^{12}$ in 2020. This will support closing the IDR $19.3 \times 10^{12}$ of the MSME financing gap and expanding the credit access of individuals in 2020 by $12.4 \%$ [3].

OJK also informed that the disbursement of credit through Fintech in Indonesia reached IDR $8.8 \times 10^{12}$ (USD $534 \times 10^{6}$ ) in the period of 7 mo to July 2018 , over three times compared to achievement in 2017, which amounted to IDR $2.56 \times 10^{12}$ (USD $175 \times 10^{6}$ ). The loan funds came from 66 local Fintech companies that have obtained operating licenses from OJK to engage in P2P Lending.

The Fintech Association in 2019 stated that there were 235 Fintech companies operating in Indonesia, more than half of the total were established in the last two years. In August 2018, 62 local Fintech companies were applying for permission to the OJK. One of the Fintech products that are already available for MSMEs in Indonesia is Investree, which lends funds for a period of 1 mo to 3 mo and several working-capital loans for one year. The total number of Investree customers is 2600 micro and SME entrepreneurs. There are also other P2P Lending such as Amartha, which has provided 130000 loans since 2010, and Gandeng Tangan, which focuses on rural micro-entrepreneurs [5].

Based on this description, it shows that P2P Lending is able to be a solution for MSMEs in financing their business operations. P2P lending offers a faster, cheaper, and easier way to finance MSMEs. But there are several challenges, as there is a large number of Peer to Peer Lending options in Indonesia. It requires MSMEs to choose carefully based on the suitability of the amount of loan with the financing requirements, loan term, and the lowest interest rates. In addition, the use of loans is only for productive purposes, namely, for working capital and business development. Misuse of the loan will have an impact on the emergence of bad debt, which in turn will result in financial distress or business bankruptcy. 


\section{Conclusion}

Indonesian MSMEs have a lot of potentials, but face difficulties in gaining access to credit. Development of technology, especially in finance namely Fintech, offers the solution to financing problems. One type of Fintech is Peer to Peer Lending. They offer a faster, cheaper, and easier way to financing MSMEs.

Peer to peer (P2P) Lending is an appropriate funding method for Indonesian MSMEs. However, the implementation requires assistance from the government so that MSMEs can borrow wisely. The loan must be productive and must match the amount needed to support the smooth operation of the business.

\section{References}

1. OECD. Survei Ekonomi OECD Indonesia, [Indonesian OECD Economic Survey], Jakarta: OECD Indonesia (2015). https://www.oecd.org/economy/OverviewIndonesia-2015-Bahasa.pdf

2. World Population Review, Total Population by Country 2019. [Online] from World Population Review http://worldpopulationreview.com (2019). [Accessed on August 28, 2019].

3. PwC. (2019). Indonesias Fintech Lending: Driving Economic Growth Through Financial Inclusion. Jakarta: PwC Indonesia. https://www.pwc.com/id/en/fintech/PwC_FintechLendingThoughtLeadership_Executi veSummary.pdf

4. IBCSD. Visi Indonesia 2050: Kontribusi Sektor Bisnis bagi Indonesia Masa Depan. [Indonesia Vision 2050: Contribution of the Business Sector to the Future of Indonesia], Jakarta: Penabulu Alliance (2015). [in Bahasa Indonesia]. https://penabulualliance.org/ibcsd-development-of-indonesia-vision-2050/ [Accessed on August 28, 2019].

5. ILO. Financing Small Businesses in Indonesia: Challenges and Opportunities, Jakarta: International Labour Organization (2019).

https://www.ilo.org/jakarta/whatwedo/publications/WCMS 695134/lang-en/index.htm

6. Bank Indonesia, Profil Bisnis Usaha Mikro, Kecil dan Menengah (UMKM), Jakarta: LPPI dan Bank Indonesia (2015). [in Bahasa Indonesia]. https://www.bi.go.id/id/umkm/penelitian/nasional/kajian/Documents/Profil\%20Bisnis \%20UMKM.pdf

7. T.T. Tambunan, Gadjah Mada International Journal of Business, 13,1:21-43(2011). https://journal.ugm.ac.id/gamaijb/article/view/5492

8. S.D. Setiawan, B. Raharjo, Fintech Berkontribusi Kembangkan UMKM. [Fintech Contributes to Develop SMEs], [Online] from: https://republika.co.id/berita/ekonomi/fintech/ppdcbc415/emfintechem-berkontribusikembangkan-umkm (2019). [in Bahasa Indonesia]. [Accessed on August 28, 2019].

9. K. Das, M. Gryseels, P. Sudhir, K.T. Tan, Unlocking Indonesia's Digital Opportunity. Jakarta: McKinsey Indonesia (2016).

https://www.mckinsey.com/ /media/McKinsey/Locations/Asia/Indonesia/Our\%20Insi ghts/Unlocking\%20Indonesias\%20digital\%20opportunity/Unlocking_Indonesias_digi tal opportunity.ashx

10. H. Sun, How P2P Finance Participates as The Solution of SME Financing Difficulty in China: A Case Study. Lisboa: ISCTE Business School Instituto Universitario de Lisboa (2015). https://repositorio.iscte-iul.pt/handle/10071/11618 
11. D.L. Chuen, L. Low, Inclusive FinTech: Blockchain, Cryptocurrency and ICO. Singapore: World Scientific Publishing Co. Pte. Ltd (2018). https://books.google.co.id/books?hl=en\&lr=\&id=HCpjDwAAQBAJ\&oi

12. Bank Indonesia, Financing SMEs: Sharing Ideas for Effective Policies. Jakarta: Bank Indonesia (2014). https://www.bi.go.id/id/umkm/penelitian/nasional/kajian/Pages/ Proceeding-Workshop-Financing-SMEs-Sharing-Ideas-for-Effective-Policies.aspx

13. R. Slamet, B. Nainggolan, Roessobiyatno, H. Ramdani, Agung, Hendriyanto, L. Ilma, Jurnal Manajemen Indonesia, 16,2:136-147(2016). [in Bahasa Indonesia]. http://journals.telkomuniversity.ac.id/ijm/article/view/319

14. Deloitte. Deloitte Report: SMEs Powering Indonesia's success, [Online] from https://www2.deloitte.com (2019). [Accessed on August 20, 2019].

15. J. Waupsh, Bankruption: How Community Banking Can Survive Fintech. New Jersey: John Wiley \& Sons, Inc (2017).

https://books.google.co.id/books?id=umZJDQAAQBAJ\&dq 